\title{
DEPOIMENTO EXCLUSIVO DE CLAUDIA TONI À RT
}

Minha vida profissional foi marcada majoritariamente pela gestão da atividade musical, ainda que eu tenha trabalhado muitas vezes com cultura em geral.

Meus irmãos e eu nunca trabalhamos juntos e também decidimos que conviver profissionalmente com meu pai nunca seria uma boa opção. Portanto, tivemos sempre trajetórias independentes, o que nos livrou de toda e qualquer prática nepotista. Alguns poderão dizer que ele, Flávia e eu fomos funcionários da USP no mesmo período, mas cada um de nós construiu seu próprio espaço, sem nunca influir naquilo que o outro fazia.

Contudo, no meu caso, é inegável que a profissão de meu pai influiu e muito na vida que construí. Eu cresci quando ele ainda vivia como músico da Orquestra Sinfônica Municipal, que era seu único ganha-pão, e regente da Orquestra de Câmara de São Paulo, atividade sem remuneração. Era uma vida dura, com não poucas privações, sob a ditadura, e com uma vida musical incipiente em torno de nós, sem estruturas sólidas para garantir um futuro melhor para a música clássica, voltada, então, estritamente para a elite madura.

Foi quase natural que eu me dedicasse a trabalhar em atividades que melhorassem nossos horizontes e que começassem a estruturar a vida cultural de São Paulo. Nós assistimos ao primeiro ensaio da Orquestra Jovem, hoje rebatizada - para profunda consternação de meu pai - de Orquestra Experimental de Repertório. O Teatro Leopoldo Fróes não está mais lá na Praça Rotary, ao lado da biblioteca, para testemunhar, mas a vida musical de São Paulo seria outra depois daquela noite.

Ele não parou de empreender em toda sua vida. Desde a Orquestra do Grêmio da Faculdade de Filosofia da USP até a Orquestra de Câmara da USP (OCAM), ele nunca desistiu, nunca esmoreceu, sempre foi um otimista e um homem cuja prática da música sempre correspondeu às suas convicções políticas. Ele sempre foi servidor público e fez jus a cada centavo que recebeu. Nunca se acomodou, nunca se omitiu, nunca deixou de brigar pelo que acreditou. 
As oportunidades que tive profissionalmente muitas vezes me permitiram apoiar e desenvolver iniciativas que tinham enorme identidade com tudo o que meu pai fez. E, certamente, o que aprendemos com ele, seja quando acertou, seja quando errou, sempre me inspirou. Ele, porém, nunca opinou ou quis me influenciar. Sempre respeitou minha independência, ainda que, quando eu tenha pedido sua opinião ou conselho, nunca tenha negado.

Os jovens músicos e os estudantes talvez não tenham a exata dimensão do que ele construiu e do quão decisivo ele foi para a educação musical de São Paulo. Mas acredito que a história the fará justiça e que as pessoas poderão conhecer a dimensão de sua vida de músico. 